\title{
Pengaruh Kompetensi Dan Kepuasan Mengajar terhadap Prestasi Kerja Guru Agama Kristen
}

\author{
Mikha Agus Widiyanto \\ Sekolah Tinggi Teologi Tenggarong \\ mikha.agus08@gmail.com \\ I Putu Ayub Darmawan \\ Sekolah Tinggi Teologi Simpson Ungaran \\ putuayub.simpson@gmail.com
}

\begin{abstract}
Teaching competence and theoretical satisfaction are factors that influence job performance. Through this research, the author tests, proves and analyzes and makes a causal relationship model the effect of competence and teaching satisfaction on the work performance of Christian Religious Education teachers. The population in this study were Christian Religious Education Teachers in Kutai Kartanegara District, East Kalimantan. The method in this study is Survey - Causal with data analysis techniques using path analysis. The results of data analysis show that: 1) There is positive and significant direct effect between teaching competencies on teaching achievement of Christian Religious Education teachers, 2) There is a positive and significant direct effect of teaching satisfaction on teaching achievement of Christian Religious Education teachers. Increasing teacher competence will have an impact on professionalism in carrying out teaching assignments and have an impact on work performance. Accompanied by high satisfaction makes the teacher responsible for his work and implement it oriented to achievement.
\end{abstract}

Keywords: Work achievement, Teacher Competence, Teaching Satisfaction

\section{Article Info}

Received date: 29 Agustus $2019 \quad$ Revised date: 20 November $2019 \quad$ Accepted date: 20 Desember 2019

\section{PENDAHULUAN}

Guru sebagai pengajar dan pendidik, salah satu faktor yang menentukan keberhasilan pendidikan. Guru berperan dalam mewujudkan pendidikan yang berkualitas, sehingga dapat dihasilkan sumber daya manusia yang handal dan berkualitas. Kualitas Pendidikan tergantung pada kualitas guru (Kumar, 2013:13). Mengacu pada data nilai Human Development Index bahwa pada tahun 2018 Indonesia mendapatkan skor 0,694 yang berada pada peringkat ke 116 dari 189 negara berada satu peringkat dengan Vietnam dan di bawah Malaysia pada peringkat 57 dan Filipina yang berada diperingkat 113 ("Human Development Reports," 2019:8-9). Kondisi SDM secara khusus dalam bidang pendidikan berpengaruh dalam pelaksanaan tugas dan prestasi kerja. Salah satu persoalan dari rendahnya mutu pendidikan nasional adalah rendahnya kompetensi guru (Sennen, 2017:21).

Chamundeswari mengungkapkan bahwa tugas mengajar yang dilakukan oleh guru merupakan sebuah 
interaksi yang bermakna antara guru dan murid, dan dalam tugas tersebut ada peran penting guru, sehingga kinerja guru penting juga. Dalam penelitian Chamundeswari menunjukkan jika guru-guru yang diteliti memiliki kepuasan kerja dan kinerja yang baik karena guru-guru menikmati fasilitas infrastruktur yang lebih baik dan lingkungan kerja yang menyenang-kan. Jadi dari penelitian Chamundeswari prestasi kerja dapat dipengaruhi oleh kepuasan kerja dan kinerja guru. Menurut Tella, Ayeni, dan Popoola (2007:5) prestasi kerja guru dipengaruhi kepuasan mengajarnya, sementara ketidakpuasan akan mem-pengaruhi dan menyebabkan kelesuan atau kurang termotivasi dalam bekerja dan berdampak pada komitmen organisasi yang rendah. Guru yang kurang puas terhadap tugas pekerjaannya maka dirinya akan kurang bertanggungjawab dan pada akhirnya akan meninggalkan pekerjaan tersebut. Menurut Abineno (2006:7-8), istilah mengajar berasal dari kata dalam bahasa Yunani, yaitu didaskein yang diartikan sebagai pekerjaan menyampaikan penge-tahuan dengan tujuan supaya orang yang diajar dapat bertindak dengan terampil. Kemudian kata didaskein diturunkan menjadi istilah didaktik. Didaktik sebagai ilmu yang mengajarkan sesuatu secara cepat dan tepat, sehingga anak didik dapat memahami serta mempraktekkannya dengan nyata. Seorang pengajar dinamakan didaskhos; sedangkan orang yang sedang mengikuti pengajaran disebut sebagai didaktos (Ismail, 2012:79-80). Mengajar sebagai pekerjaan yang dilakukan untuk membuat seseorang atau sekelompok orang yang diajar memiliki seperangkat pengetahuan dan keterampilan sehingga menjadikan dirinya inovatif dan kreatif.

Prestasi kerja merupakan seperangkat perilaku yang menunjukkan pada kesungguhan dan kemampuannyadalam melaksanakan tugas mengajar (Colquitt, LePine, \& Wesson, 2013:32; Dizgah, Chegini, \& Bisokhan,
2012:1735). Kemampuan dan kesanggupannya tersebut yang akan membawa keberhasilan dalam mewujudkan tujuan pembelajaran dalam membentuk peserta didik yang berprestasi dan memiliki karakter mulia sesuai dengan kehendak Kristus. Prestasi kerja guru sebagai hasil dan pengembangan yang dicapai oleh guru dalam melakukan tugas dan tanggung jawab yang diberikan berdasarkan faktor kemampuan, presentasi atau keterampilan, latar belakang keluarga, status sosial, pengalaman, usia, jenis kelamin, etnis, kualifikasi akademik, pengalaman kerja, sumber daya, kepemimpinan, penghargaan, struktur dan sifat pekerjaan, persepsi, sikap, kepribadian, pembelajaran, dan motivasi (Pardimin \& Huda, 2018:392). Sedarmayanti (2001:120) menyatakan bahwa prestasi kerja meliputi beberapa aspek yaitu: 1) Quality of Work, 2) Promptness, 3) Initiative, 4) capability, dan 5) communication yang dijadikan ukuran dalam mengadakan pengkajian tingkat prestasi kerja seseorang. Sedangkan Bernardin dan Russell (1993:380) menyatakan bahwa ukuran prestasi kerja, yaitu: 1) Quality, 2) Quantity, 3) Timeliness, 4) Cost effectiveness, 5) Need for supervision, 6) Interpersonal impact.

Menurut Colquitt, LePine dan Wesson (2013:96), dan Luthans (2011:141) bahwa kepuasan kerja sebagai suatu keadaan emosi yang menyenangkan atau positif sebagai hasil penilaian dari satu pekerjaan atau pengalaman kerja (Colquitt, LePine dan Wesson, 2013:96); Luthans, 2011:141). Kepuasan kerja sebagai persepsi seseorang mengenai seberapa baik pekerjaan yang dilakukan memberikan hasil yang dinilai penting (Luthans, 2011:141). Suatu pekerjaan dinilai penting, positif atau negatif tergantung pada persepsi dan penilaiannya terhadap pekerjaan itu sendiri. Mencakup kesulitan-kesulitan yang dihadapi, tantangantantangan dan hubungan yang terjadi dengan rekan kerja (Muhaimin, 2004:36).

Menurut Javed, Balouch, dan Hassan (2014:120) bahwa kepuasan kerja sangat 
penting bagi organisasi. Pegawai yang memiliki kepuasan tinggi maka akan berdampak pada peningkatan organisasi. Ketidakpuasan pegawai memiliki efek buruk pada efisiensi dan efektivitas organisasi. Kepuasan memiliki potensi dalam mempengaruhi berbagai sikap dalam lembaga dan memberikan kontribusi dalam peningkatan kesejahteraan (George \& Jones, 2012:102). Peningkatan pada posisi pegawai, akan meningkatkan kepuasannya terhadap pekerjaan. Peningkatan itu mendatangkan manfaat yang lebih besar, otonomi, dan menghasilkan lebih banyak karya kreatif (Shaju \& Subhashini, 2017:121). Kepuasan ini akan mendorong perilakunya untuk menampilkan hasil kerja yang baik, berkualitas dan mengungguli standar yang ditetapkan (excelent).

Kepuasan kerja memiliki lima dimensi, yaitu: 1) The work itself, dalam hal ini pekerjaan memberikan tugas yang menarik, kesempatan untuk belajar, dan kesempatan menerima tanggungjawab; 2) $P a y$, gaji sebagai upah dari pelaksanaan pekerjaan dipandang pantas dibandingkan oleh orang lain dalam organisasi; 3) Promotion opportunities, kesempatan untuk maju atau mendapatkan promosi atau jabatan dalam organisasi; 4) Supervision, kemampuan organisasi untuk memberikan bantuan teknis dan dukungan perilaku; 5) Coworkers, rekan kerja pandai secara teknis dan memberikan bantuan secara sosial. (Luthans, 2011:141; Robbins \& Judge 2013)

Menurut Wijaya dan Rusyan (1991:8), Mulyasa (2007:8), dan Sanjaya (2005:145) bahwa kompetensi merupakan gambaran hakikat kualitatif dari perilaku guru yang menunjukkan pengetahuan, keterampilan dan kemampuan dalam melaksanakan tugas pekerjaan untuk mencapai tujuan yang diharapkan. Kompotensi guru mengarah pada perilakunya dalam kegiatan belajar-mengajar. Perilaku tersebut yang menujukkan kemampuannya sebagai tenaga profesional dan yang mengarahkan dirinya dalam mencapai tujuan pembelajaran yang telah ditetapkan. Kompotensi guru sebagai kemampuan yang berkaitan dengan pe-nyelesaian tugas-tugas keguruan. Kemampuan tersebut yang berhubungan langsung dengan kinerja yang ditampilkan (Sanjaya, 2005:145). Kompetensi guru meliputi kompetensi profesional, kompetensi pedagogik, kompetensi kepribadian atau personal dan kompetensi sosial Menurut (Mulyasa, 2007:135; Sanjaya, 2005:146; Mary \& Darmawan, 2018). Kompetensi profesional berkenanan dengan kemampuan dalam mengelola atau menguasai materi pembelajaran, pemahaman perkembangan peserta didik, manajemen pembelajaran, penggunaan teknologi informasi, penggunaan model pembelajaran, pengembangan kurikulum dalam proses pembelajaran, evaluasi pembelajaran dan pengembangan potensi peserta didik dalam proses pembelajaran dalam kegiatan sekolah (Pahrudin, Martono, \& Murtini, 2016:333).

Hakim (2015:3) menyatakan bahwa kompetensi profesional berkenaan dengan penguasaan materi pembelajaran yang luas dan mendalam, meliputi penguasaan konten kurikulum dan substansi mata pelajaran ilmiah secara filosofis. Untuk dapat melaksanakan tugas mengajarnya dengan baik, profesional dan dapat dipertanggung-jawabkan, maka guru harus memiliki kepribadian yang mantap, stabil dan dewasa (Mulyasa, 2007:121). Sedangkan kompetensi sosial sebagai kemampuan guru sebagai bagian dari masyarakat, yang tercermin melalui komunikasi dan hubungan baik yang dibangun dengan peserta didik, rekan sejawat, pimpinan, orantua peserta didik dan masyarakat lainnya (Mulyasa, 2007:173).

Rumusan masalah penelitian ini adalah 1) Apakah terdapat pengaruh kompetensi terhadap kepuasan mengajar guru Pendidikan Agama Kristen? 2) Apakah terdapat pengaruh kompetensi terhadap prestasi kerja guru 
Pendidikan Agama Kristen? 3) Apakah terdapat pengaruh kepuasan mengajar terhadap prestasi kerja guru Pendidikan Agama Kristen?

Penelitian ini bertujuan untuk menguji, membuktikan dan menganalisis serta membuat suatu model hubungan kausal pengaruh kompetensi dan kepuasan mengajar terhadap prestasi kerja guru Pendidikan Agama Kristen.

\section{METODE PENELITIAN}

Penelitian ini merupakan penelitian kuantitatif dengan metode survei kausal. Dikatakan survei dikarenakan data yang dikaji merupakan data sampel yang diambil dari populasi dan digunakan untuk generalisasi (Kerlinger, 2004:660). Sedangkan kasual untuk mengetahui hubungan yang sifatnya kausal antar variabel yang dikaji. Variabel dalam penelitian ini adalah prestasi kerja guru PAK sebagai variabel endogenus. Sedangkan kompetensi dan kepuasan mengajar sebagai variabel eksogenus. Penelitian ini dilakukan di Kabupaten Kutai Kartanegara dengan sampel penelitian adalah guru Agama Kristen. Teknik pengambilan sampel dengan menggunakan stratified random sampling. yaitu pengambilan sampel secara acak berdasarkan strata yang ada dalam populasi. Strata yang dimaksud dalam penelitian ini bahwa guru berasal dari dua lembaga penbdidikan dengan jenjang yang berbeda, yaitu guru Pendidikan Agama Kristen yang mengajar pada jenjang Pendidikan Dasar, Pendidikan Menegah Pertama dan Atas di Kabupaten Kutai Kartanegara dengan jumlah sampel sebanyak 126 orang.
Teknik pengumpulan data menggunakan kuesioner tertutup dengan skala perilaku. Pernyataan-pernyataan Instrumen penelitian dengan pilihan jawaban Sangat Sesuai (SS), Sesuai (S), Kadang-kadang Sesuai (KS), Tidak Sesuai (TS), dan Sangat Tidak Sesuai (STS). Istrumen penelitian sebelum diguna-kan dalam pengumpulan data dilakukan uji coba kepada sampel penelitian dan dilakukan pengujian validitas dan reliabilitas.

Pengujian validitas menggunakan item validity dan pengujian reliabilitas menggunakan internal consistency dengan metode Alpha Cronbach. Instrumen kompetensi guru terdiri dari 39 item pertanyaan yang valid dengan koefisien reliabilitas sebesar 0,961. Instrumen kepuasan kerja guru terdiri dari 29 item pertanyaan yang valid dengan koefisien reliabilitas sebesar 0,913. Sedangkan instrumen prestasi kerja guru terdiri dari 36 item pertanyaan yang valid dengan koefisien reliabilitas sebesar 0,948 .

Teknik analisis data menggunakan korelasi, regresi sederhana dan path analysis (Analisis Jalur). Analisis jalur (Path Analysis) merupakan salah satu teknik satistika parameterik yang digunakan untuk menguji hubungan antar variabel yang sifatnya kausal (Widiyanto, 2013).

\section{HASIL PENELITIAN DAN PEMBAHASAN}

\section{Hasil Penelitian}

Berdasarkan analisis deskriptif diperoleh hasil sebagai berikut:

Tabel 1. Analisis Deskripsi Data Penelitian

\begin{tabular}{lrrrrr}
\hline \multicolumn{1}{c}{ Variabel } & N & Minimum & Maximum & Mean & Std. Deviation \\
\hline Prestasi Kerja Guru & 126 & 125 & 173 & 149.71 & 11.004 \\
\hline Kepuasan Mengajar & 126 & 137 & 184 & 159.67 & 9.863 \\
\hline Kompetensi Guru & 126 & 101 & 134 & 117.71 & 8.306 \\
\hline Sumber: Data penelitian & & & &
\end{tabular}

Berdasarkan analisis data menunjukkan bahwanilai rata-rata pretsasi kerja guru sebesar 149,706 dan simpangan baku sebesar 11,004.
Sebanyak 87guru atau 69,05\%yang memiliki skor di atas rata-rata atau dalam kategori prestasi kerjanya baik. Sedangkan sebanyak 39 
orang atau 30,95\% yang mendapatkan skor di bawah rata-rata. Nilai rata-rata kompetensi guru didapatkan sebesar 159,675 dan simpangan baku sebesar 9,863. Sebanyak 84 guru atau $67,67 \%$ yang memiliki skor kompetensi lebih dari nilai rata-rata dan sebanyak 61 orang atau $48,41 \%$ yang memiliki skor di bawah rata-rata. Kompetensi guru menunjukkan kategori sudah baik. Sedangkan data variable kepuasan mengajar gurudiperolehnilai rata-rata sebesar 117,706 dan simpangan baku sebesar 8,306. Sebanyak 83 guru atau $76,19 \%$ yang mendaptkan skor di atas rata-rata dan sebanyak 53 orang atau $42,06 \%$ yang mendaptkan skor di bawah ratarata. Dengan demikian, guru memiliki tingkat kepuasan yang cukup baik.

Berdasarkan hasil analisis data yang disajikan dalam tabel 2 dan 3 serta Path Diagram yang didasarkan pada koefisien jalur dan koefisien $\mathrm{t}$ yang analisisnya menggunakan LISREL 8.8, hasilnya disajikan berikut ini:

Tabel 2. Pengujian Pengaruh Kompetensi Guru terhadap Kepuasan Mengajar

\begin{tabular}{|c|c|c|c|c|c|}
\hline \multirow{3}{*}{ Model } & \multicolumn{3}{|c|}{ Coefficients $^{\mathbf{a}}$} & \multirow{3}{*}{$\mathrm{t}$} & \multirow{3}{*}{ Sig. } \\
\hline & \multicolumn{2}{|c|}{ Unstandardized Coefficients } & Standardized Coefficients & & \\
\hline & B & Std. Error & Beta & & \\
\hline (Constant) & 76.747 & 10.128 & & 7.577 & .000 \\
\hline Kompetensi Guru & .705 & .086 & .593 & 8.208 & .000 \\
\hline a. Dependent Variab & e: Kepuasan I & engajar & & & \\
\hline
\end{tabular}

Tabel 3. Pengujian Pengaruh Kompetensi Guru terhadap Prestasi Kerja Guru; Pengaruh Kepuasan Mengajar terhadap Prestasi Kerja Guru Coefficients $^{\mathbf{a}}$

\begin{tabular}{|c|c|c|c|c|c|}
\hline \multirow[t]{2}{*}{ Model } & \multicolumn{2}{|c|}{ Unstandardized Coefficients } & Standardized Coefficien & \multirow[t]{2}{*}{$\mathrm{t}$} & \multirow[t]{2}{*}{ Sig. } \\
\hline & B & Std. Error & Beta & & \\
\hline (Constant) & 2.523 & 8.995 & & .280 & .780 \\
\hline 1 Kepuasan Mengajar & 223 & .066 & .2 & 3.382 & .001 \\
\hline Kompetensi Guru & .948 & .078 & .7 & 12.108 & .000 \\
\hline
\end{tabular}

a. Dependent Variable: Prestasi Kerja Guru

Sumber: Data penelitian

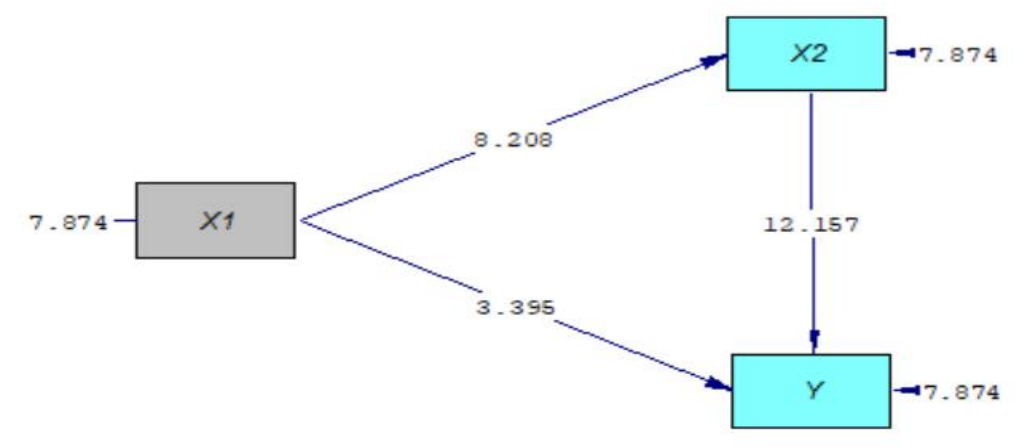

Chi-Square=0.00, df=0, P-value=1.00000, RMSEA=0.000

Gambar 2. Hasil Pengujian Signifikansi Koefisien Jalur Berdasarkan Koefisien t

Sumber: Data penelitian 
Berdasarkan gambar di atas diperoleh bahwa data dengan model adalah fit (telah memenuhi Goodness of Fit). Hal ini ditunjukkan dengan koefisien Chi-Square, $P$ value dan RMSEA (Root Mean Square Error of Approximation). Koefisien Chi-Square menunjukkan nilai yang kecil yang mencapai 0,00 . Koefisien P-value yang disyaratkan adalah lebih besar dari 0,05 sedangkan hasil analisis menunjukkan sebesar 1,000. Sedangkan untuk koefisien RMSEA yang disyaratkan lebih kecil dari 0,08 sedangkan hasil analisis menunjukkan sebesar 0,000.Berdasarakan pada kriteria ini, maka secara umum model yang diajukan dalam penelitian ini telah memenuhi kelayakan sebuah model. Langkah selanjutnya adalah melakukan analisis individual untuk masingmasing jalur untuk mengetahui pengaruh yang signifikan antar variabel yang didasarkan pada uji t.

\section{Pengaruh kompetensi terhadap} kepuasan mengajar guru. Berdasarkan hasil analisis diperoleh besarnya koefisien jalur kompetensi terhadap kepuasan mengajar guru sebesar 0,593 dengan $t$ hitung sebesar 8,208 yang lebih besar dari t kriteria $(8,208>1,96)$, maka koefisien jalur sebesar 0,593 adalah signifikan. Dengan demikian disimpulkan bahwa terdapat pengaruh langsung yang signifikan kompetensi terhadap kepuasan mengajar guru.

\section{Pengaruh kompetensi terhadap} prestasi kerja guru. Berdasarkan hasil analisis diperoleh besarnya koefisien jalur kompetensi terhadap prestasi kerja guru sebesar 0,200 dengan $\mathrm{t}$ hitung sebesar 3,382 yang lebih besar dari $\mathrm{t}$ kriteria $(3,382>1,96)$, maka koefisien jalur sebesar 0,200 adalah signifikan. Dengan demikian disimpulkan bahwa terdapat pengaruh langsung yang signifikan kompetensi terhadap prestasi kerja guru.

\section{Pengaruh kepuasan mengajar} terhadap prestasi kerja guru. Berdasarkan hasil analisis diperoleh besarnya koefisien jalur kompetensi terhadap prestasi kerja guru sebesar 184
0,716 dengan $\mathrm{t}$ hitung sebesar 12,157 yang lebih besar dari $t$ kriteria $(12,157>$ 1,96), maka koefisien jalur sebesar 0,716 adalah signifikan. Dengan demikian disimpulkan bahwa terdapat pengaruh langsung yang signifikan kepuasan mengajar terhadap prestasi kerja guru.

\section{Pembahasan}

Kompetensi guru mempengaruhi prestasi kerjanya dan kompetensi tersebut merupakan prasyarat bagi guru untuk dapat melaksanakan tugasnya dengan baik. Guru yang kompeten dirinya akan mampu menampilkan perilaku kerja sesuai dengan harapan dan berprestasi. Hasil penelitian menunjukkan bahwa terdapat pengaruh langsung yang signifikan kompetensi terhadap kepuasan mengajar guru dan terdapat pengaruh langsung yang signifikan kompetensi terhadap prestasi kerja guru. Karena kompetensi guru mempengaruhi kinerja guru maka kompetensi guru perlu ditingkatkan. Dari penelitian yang dilakukan oleh Darmawan (2017) menunjukkan jika profesionalitas guru dapat ditingkatkan dengan cara meningkatkan pengalaman mengajar dalam berbagai pendekatan, meningkatkan jenjang pendidikan dan memberi pelatihan, guru melakukan lesson study, adanya supervisi oleh kepala sekolah, serta adanya minat dan motivasi guru untuk terus meningkatkan kompetensinya.

Hasil penelitian menunjukkan bahwa terdapat pengaruh langsung yang signifikan kepuasan mengajar terhadap prestasi kerja guru. Hasil tersebut relevan dengan penelitian Chamundeswari (2013). Prestasi kerja guru sebagaimana dapat lebih baik karena guru mengalami kepuasan kerja. Faktor dalam kepuasan kerja dalam penelitian Chamundeswari (2013) adalah adanya lingkungan kerja yang menyenangkan. Sama dengan penelitian Ma dan MacMillan (1999) kepuasan kerja dapat terwujud ketika ada kondisi lingkungan kerja yang baik. Oleh sebab itu usaha meningkatkan prestasi kerja guru dapat dilakukan dengan meningkatkan 
kepuasan kerjanya. Guru yang memiliki kepuasan kerja tinggi dirinya akan berusaha menampilkan prestasi kerja yang tinggi pula. Hal ini dikarenakan dirinya menyukai pekerjaan yang dilakukan dan adanya kepuasan ketika melaksanakannya. Kepuasan tersebut yang membuat dirinya berusaha menampilkan performance yang baik sesuai dengan standar perilaku yang ditetapkan lembaga pendidikan di mana dirinya mengabdi. Ngunia, Sleegersb, dan Denessen (2006) mengungkapkan bahwa kepuasan kerja akan mempengaruhi perilaku organisasi guru termasuk dalam hal ini adalah meningkatkan kualitas kerja.

Davis dan Wilson (2000) menjelaskan bahwa kepuasan kerja dapat terwujud dengan adanya pemberdayaan dan motivasi terhadap guru sehingga akhirnya dapat meningkatkan kualitas kerjanya. Pemberdayaan yang baik dilakukan dengan pemberian tugas yang sesuai dengan bidang kemampuan dan keahlian dan memberikan kompensasi kerja sesuai dengan beban kerja dan keahliannya. Dengan pemberian penghargaan yang sesuai dengan beban kerja akan membuat dirinya merasa diperlakukan secara adil oleh lembaga sekolah. Kepuasan yang dirasakan guru akan membuatnya memberikan timbal balik dengan bekerja yang sebaik-baiknya dan berusaha menampilkan prestasi kerja yang tinggi.

\section{SIMPULAN DAN SARAN}

\section{Simpulan}

Berdasarkan hasil analisis disimpulkan bahwa: 1) Terdapat pengaruh kompetensi terhadap kepuasan mengajar guru yang ditunjukkan dengan koefisien jalur sebesar 0,593 yang signifikan pada $\alpha=0,05$; Meningkatkan kompetensi guru akan meningkatkan kepuasan dirinya dalam melaksanakan tugas mengajarnya. 2) Terdapat pengaruh kompetensi terhadap perastasi kerja guru yang ditunjukkan dengan koefisien jalur sebesar 0,200 yang signifikan pada $\alpha=0,05$; Meningkatkan kompetensi guru akan meningkatkan prestasi kerjanya menjadi semakin tinggi. 3) Terdapat pengaruh kompetensi terhadap prestasi kerja guru yang ditunjukkan dengan koefisien jalur sebesar 0,716 yang signifikan pada $\alpha=0,05$. Guru yang memiliki tingkat kepuasan yang tinggi akan dapat menunjukkan prestasi kerja yang baik dalam melaksnaakan tugas mengajarnya.

\section{Saran}

Berdasarkan hasil penelitian sebagaimana yang telah diungkpakan, maka disampaikan saran bahwa guru hendaknya meningkatkan kompetensi sesuai dengan bidang tugasnya. Guru Pendidikan Agama Kristen tidak hanya sekedar memiliki kemampuan dalam aspek profesional saja, melainkan kompetensi pedagogik, sosial dan kepribadian yang menjadi satu kesatuan tidak terpisahkan. Kompetensi yang memadai dan tinggi akan menjadikan guru dapat menampilkan prestasi kerja yang lebih baik. Guru hendaknya tidak cepat merasa puas diri dari pencapaian dalam pelaksanaan tugas mengajar, melainkan terdorong untuk terus meningkatkan kepuasannya melalui pen-capaian-pencapaian prestasi mengajar yang lebih baik.

\section{DAFTAR PUSTAKA}

Abineno, J. L. Ch. (2006). Sekitar katekese gerejawi. Jakarta: BPK Gunung Mulia.

Chamundeswari, S. (2013). Job Satisfaction and Performance of School Teachers. International Journal of Academic Research in Business and Social Sciences, 3(5), 420-428.

Colquitt, J. A., LePine, J. A., \& Wesson, M. J. (2013). Organizational Behavior: Improving Performance and Commitment in the Workplace (3th ed.). New York: McGraw-Hill Companies, Inc.

Darmawan, I. P. A. (2017). Faktor Yang Mempengaruhi Profesionalitas Guru. Prosiding Seminar Nasional 
Pendidikan Agama Kristen dan call for papers. Presented at the Seminar Nasional Pendidikan Agama Kristen dan call for papers, Ungaran. Retrieved from

http://semnas.sttsimpson.ac.id/index.ph $\mathrm{p} / \mathrm{SNPK} /$ article/view/19

Davis, J., \& Wilson, S. M. (2000). Principals' Efforts to Empower Teachers: Effects on Teacher Motivation and Job Satisfaction and Stress. The Clearing House: A Journal of Educational Strategies, Issues and Ideas, 73(6), 349-353.

https://doi.org/10.1080/0009865000959 9442

Dizgah, M. R., Chegini, M. G., \& Bisokhan, R. (2012). Relationship between Job Satisfaction and Employee Job Performance in Guilan Public Sector. Journal of Basic and Applied Scientific Research, 2(2), 1735-1741.

George, J. M., \& Jones, G. R. (2012). Understanding and Managing Organizational Behavior. Retrieved from/content/one-dot-com/one-dotcom/us/en/higher-

education/product.html

Hakim, A. (2015). Contribution of Competence Teacher (Pedagogical, Personality, Professional Competence and Social) On the Performance of Learning. The International Journal Of Engineering And Science (IJES), 4(2), 1-12.

Human Development Reports. (2019). Retrieved August 29, 2019, from http://hdr.undp.org/en/2018-update

Ismail, A. (2012). Ajarlah Mereka Melakukan Kumpulan Karangan Seputar pendidikan Agama Kristen. Jakarta: BPK Gunung Mulia.
Kerlinger, F. N. (2004). Asas-Asas Penelitian Behavioral. Retrieved from http://ugmpress.ugm.ac.id/id/product/a gro-fauna/asas-asas-penelitianbehavioral

Kumar, M. S. V. (2013). The Influence of Teacher's Professional Competence on Students' Achievement. IOSR Journal of Engineering, 3(11), 12-18. https://doi.org/10.9790/3021031121218

Luthans, F. (2011). Organizational Behaviour (12th ed.). New York: McGraw-Hill Companies, Inc.

Ma, X., \& MacMillan, R. B. (1999). Influences of Workplace Conditions on Teachers' Job Satisfaction. The Journal of Educational Research, 93(1), 39-47. https://doi.org/10.1080/0022067990959 7627

Mary, E., \& Darmawan, I. P. A. (2018). Guru Agama Kristen Yang Profesional. Salatiga: Satya Wacana University Press.

Muhaimin, M. (2004). Hubungan Antara Kepuasan Kerja Dengan Disiplin Kerja Karyawan Operator Shawing Computer Bagian Produksi Pada PT Primarindo Asia Infrastruktur Tbk Di Bandung. Jurnal Psyche, 1(1), 36.

Mulyasa, H. E. (2007). Standar Kompetensi Dan Sertifikasi Guru. Bandung: PT Remaja Rosdakarya.

Nguni, S., Sleegers, P., \& Denessen, E. (2006). Transformational and transactional leadership effects on teachers' job satisfaction, organizational commitment, and organizational citizenship behavior in primary schools: The Tanzanian case. School Effectiveness and School Improvement, $17(2)$,

145-177. 
https://doi.org/10.1080/0924345060056 5746

Pahrudin, P., Martono, T., \& Murtini, W. (2016). The Effect of Pedagogic Competency, Personality, Professional and Social Competency Teacher to Study Achievement of Economic Lesson in State Senior High School of East Lombok District Academic Year 2015/2016. Proceeding of the International Conference on Teacher Training and Education, 2(1), 332-345.

Pardimin, P., \& Huda, M. (2018). Investigating Factors Influencing Mathematics Teaching Performance: An Empirical Study. International Journal of Instruction, 11(3), 391-402. https://doi.org/10.12973/iji.2018.11327 a

Robbins, S. P., \& Judge, T. (2013). Organizational behavior (15th ed). Boston: Pearson.

Sanjaya, W. (2005). Pembelajaran dalam Implementasi Kurikulum Berbasis Kompotensi. Jakarta: Kencana Prenata Media Group.

Sedarmayanti, M. (2001). Sumber daya manusia dan produktivitas kerja. Bandung: CV. Mandar Maju.
Sennen, E. (2017). Problematika Kompetensi Dan Profesionalisme Guru. Prosiding Himpunan PGSD 2017, 16-21. Maluku: Universitas Pattimura.

Shaju, M., \& Subhashini, D. (2017). A study on the impact of Job Satisfaction on Job Performance of Employees working in Automobile Industry, Punjab, India. Journal of Management Research, 9(1), 117-130. https://doi.org/10.5296/jmr.v9i1.10420

Tella, A., Ayeni, C. O., \& Popoola, S. O. (2007). Work Motivation, Job Satisfaction, and Organisational Commitment of Library Personnel in Academic and Research Libraries in Oyo State, Nigeria. Library Philosophy and Practice (e-Journal), 118, 1-16.

Widiyanto, M. A. (2013). Statistika Terapan: Konsep dan Aplikasi SPSS/LISREL dalam Penelitian Pendidikan, Psikologi dan Ilmu Sosial Lainnya. Jakarta: Elex Media Komputindo.

Wijaya, C., \& Rusyan, A. T. (1991). Kemampuan dasar guru dalam proses belajar-mengajar. Bandung: Remaja Rosdakarya. 